\title{
Ecological Characteristics Study of the Vegetation Cover for the Protected Area Faculty of Agriculture at the University of Tripoli-Libya
}

\author{
Malakalrahma Abdurazag Alftisi' ${ }^{1}$, Raneem Banur Osman ${ }^{1}$, Rokaia Mohammed \\ Elalem $^{1}$, Fathi Goma Al-Sghair ${ }^{1}$ \\ ${ }^{I}$ Department of Botany, Faculty of Sciences, University of Tripoli, Tripoli, Libya \\ fathi_alsghair@yahoo.com
}

\begin{abstract}
The aim of this research was to investigate the vegetation characteristics to determine the dominant species because the selected study area never has been ecologically studied before. The study was carried out in the period from April to the end of May 2018 two trips per week. To achieve the study, two methods were used Quadrat Method and Linestransect Method. 19 lines-transect were randomly distributed with a length of 50 meters in the study area. A total of 92 quadrats $4 \mathrm{~m}^{2}$ selected for perennial plants and 60 quadrats $1 \mathrm{~m}^{2}$ for annual plants (grasses) were distributed to the Line-transect; all plant species and their numbers that appeared in the quadrat were recorded. Vegetation characteristics (density, frequency, and abundance) and their relative values of each plant species were calculated from quadrat, whereas cover and the relative cover was calculated from Line-transect. The results showed that the highest density in annual plants was 32.1 plant $/ \mathrm{m}^{2}$ for Stipacapensis followed by Scabiosaarenaria with 15.6 plants $/ \mathrm{m}^{2}$, while in perennial plants was found $\left(14.7\right.$ plant $\left./ \mathrm{m}^{2}\right)$ for Plantagoalbicans followed by Helianthemumlippii density with (3.26 plant / $\left.\mathrm{m}^{2}\right)$. The obtained results also showed that S.Arenaria has the highest frequency $80 \%$, then S. capensis with $78.30 \%$ in annual plants, in perennial plantsP. albicans has the highest frequency (97.8\%) followed by $\mathrm{H}$. lippii with (70.6\%). It appears from results obtained that the highest cover recorded was (15.8\%) for S. capensis followed by P. albicans (12.4\%). From the results, the annual plants have the highest value were 187.92 for plant species $S$. capensis followed by $S$. arenaria with 148.8. Through the results obtained, the plantcommunity of the study area is Stipa capensis - Scabiosa arenaria Community.
\end{abstract}

Keywords: Protected area; Vegetation characteristics; Quadrats Method; Lines-transect Method.

\section{Introduction}

Protected areas are places where conscious efforts are made to preserve not only wild species but also the ecosystems in which species live. Protected areas may be the only natural or near-natural ecosystems remaining in large areas (Cardinale et al. 2012). According to IUCN (1994), a protected area is an area of land and/or sea, especially dedicated to the protection and maintenance of biological diversity, and of natural and associated cultural resources, and managed through legal or other effective means. Protected areas are important tools for the conservation of biodiversity by protecting species, habitats and other biodiversity features within their boundaries (CBD, 2010). Throughout the world, protected areas are the key to conserving biodiversity, and they providing food, fiber, and other ecosystem services essential for human sustenance (DeFries et al. 2007). The plants grow in communities; each community is characterized by species diversity, growth forms, and structures, dominance successional trends. A certain analytical character such as frequency, densities, and the abundance of species in a community is expressed in quantity to know their dominance. The quadrat method and line transect method serve the purpose of analytical characters (Mahajan and Fatima, 2017). The 
quadrat methodmost widely used (Sorrells \& Glenn, 1991) to estimate the population density of each species in a given community.Density is one of the most commonly sampled parameters (Askari et al, 2013), it plays a significant role as one of the important features in assessing rangelands characteristics of and changes in plant communities (Balouchi et al., 2017). Estimation of vegetation cover is the most widely used method of characterizing herbaceous and shrub vegetation (Gayton, 2013). Line transect sampling can be covered more ground in a given time than for quadrat sampling, within quadrats must be counted all plants. In many circumstances, standard line transect sampling is very effective for plant populations (Buckland, et.al 2007). An Importance Value (IV) for each species is obtained from the combined contribution of the relative cover, relative density and relative frequency of each species in the community, the importance values range from 0 to 300 (Liu et al., 2017). The aim of this research was to investigate the vegetation characteristics (density, frequency, abundance, and cover) and the relative values of each plant species to determine the dominant species because the selected study area never has been ecologically studied before.

\section{Material and Methodology}

\subsection{Study Area and Site Descriptions}

The protected area is located within the campus of the University of Tripoli, between longitude (32505668 and 32504020) and latitudes (13134779 and 1314644). The total area is 75 hectares; the target area for the study is about 25 hectares in the research station of the Faculty of Agriculture (Fig. 1).The area is characterized by the nature of a different flat land in the rise and it's about $8 \mathrm{Km}$ from the sea, and it rises to about $11 \mathrm{~m}$ above the sea level. The study area lies within the influence of the Mediterranean climate, warm rain in the winter, and hot dry summers (Betelmal, 2010). Climate is one of the most important factors affecting biodiversity, vegetation distribution, and soil composition, and the high temperature affects vegetation and the dominant species.

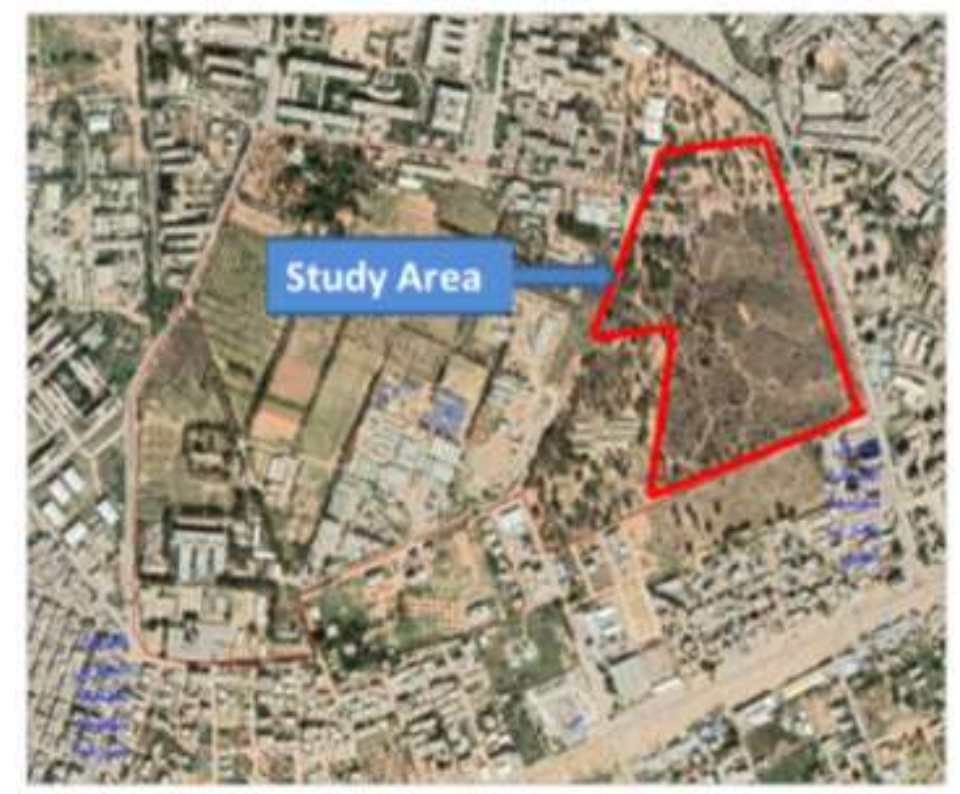

Figure 1. Location of Study area in the University of Tripoli (Via https://www. Google Earth). 


\subsection{Field Methods}

The study was carried out in the period from April to the end of May 2018 two trips per week. In the field study, Quadrat Method was used to collect environmental characteristics of the study area; the quadrat area was selected according to Cain and Castro (1959), quadrat counting is one of the oldest techniques of data collecting from the field (Krebs, 1999).

A quadrat $4 \mathrm{~m}^{2}(2 \mathrm{~m} \times 2 \mathrm{~m})$ was selected for perennial plants (small shrubs, tallherbs), and $1 \mathrm{~m}^{2}(1 \mathrm{~m} \times 1 \mathrm{~m})$ for annual plants (grasses). The Line-transect method is used to estimate the cover of the plant species. 19 lines-transect were randomly distributed with a length of 50 meters in the study area, the coordinates of each line-transect were recorded by GPS (Garman etrex). A total of 92 quadrats of $4 \mathrm{~m}^{2}$ and 60 quadrats of $1 \mathrm{~m}^{2}$ were distributed to the Linetransect; all plant species and their numbers that appeared in the quadrat were recorded. Vegetation characteristics (density, frequency, and abundance) and their relative values of each plant species were calculated from quadrat, whereas cover and the relative cover was calculated from Line-transect. Relative values of density, frequency, and cover were used to calculate the importance value.All plant species were identified and named according to Flora of Libya.

\section{Results}

\subsection{Ecological Characteristics of Annual Plants}

The quadrat $1 \mathrm{~m}^{2}$ was used for annual plants to study ecological characteristics. The results showed that the highest density was 32.1 plant $/ \mathrm{m}^{2}$ for Stipacapensis with relative density $28.90 \%$ followed by Scabiosaarenaria with 15.6 plant $/ \mathrm{m}^{2}$ with relative density $13.2 \%$, and also showed Scabiosaarenaria has the highest frequency $80 \%$, then Stipacapensis with $78.30 \%$. The highest value of Abundance was 44.88 plant / quadrat for Stipacapensis followed by Scabiosaarenaria with19.5 plant / quadrat (Table 1).

Table 1.Shows the Ecological Characteristics of Annual Plants

\begin{tabular}{|l|c|c|c|c|c|c|}
\hline Species & $\begin{array}{c}\text { Density } \\
(\text { Plant/m }\end{array}$ & $\begin{array}{c}\text { Relative } \\
\text { density } \\
(\%)\end{array}$ & $\begin{array}{c}\text { Frequency } \\
(\%)\end{array}$ & $\begin{array}{c}\text { Relative } \\
\text { frequency } \\
(\%)\end{array}$ & $\begin{array}{c}\text { Abundance } \\
\text { (Plant/ } \\
\text { quadrat) }\end{array}$ & $\begin{array}{c}\text { Relative } \\
\text { Abundance } \\
\%\end{array}$ \\
\hline $\begin{array}{l}\text { Aegilopus kotschyi } \\
\text { Boiss. }\end{array}$ & 8 & 6 & 5 & 0.81 & 16 & 5.94 \\
\hline $\begin{array}{l}\text { Avena barbata } \text { Pott ex } \\
\text { Link }\end{array}$ & 0.25 & 0.21 & 5 & 0.81 & 5 & 1.85 \\
\hline Anagallis arvensis L. & 4.03 & $\% 3.4$ & 25 & 4.09 & 16.3 & 6.05 \\
\hline $\begin{array}{l}\text { Centaurium pulchellum } \\
\text { (Swartz) Druce }\end{array}$ & 0.21 & 0.18 & 7 & 1 & 3.25 & 1.20 \\
\hline Eragrostis cilianensis & 5.1 & 4.33 & 33.0 & 5.39 & 15.3 & 5.68 \\
\hline $\begin{array}{l}\text { Hippocrepisbicontorta } \\
\text { Loisel. }\end{array}$ & 2.15 & 1.80 & 21.6 & 3.53 & 9.92 & 3.68 \\
\hline $\begin{array}{l}\text { Hussoniapinnata } \text { (Viv.) } \\
\text { Jafri }\end{array}$ & 0.18 & 0.15 & 6.60 & 1.07 & 2.75 & 1.02 \\
\hline Linumstrictum L. & 0.51 & 0.43 & 3.30 & 0.53 & 15.5 & 5.76 \\
\hline $\begin{array}{l}\text { Lotus halophilus } \\
\text { Boiss.et Spruner }\end{array}$ & 7.93 & 6.74 & 56.60 & 9.16 & 14 & 5.20 \\
\hline $\begin{array}{l}\text { Reichardia tingitana } \\
\text { (L.) Roth }\end{array}$ & 0.15 & 0.12 & 6.60 & 1.07 & 2.25 & 0.83 \\
\hline $\begin{array}{l}\text { Scabiosa arenaria } \\
\text { Forssk. }\end{array}$ & 15.6 & 13.2 & 80 & 13.08 & 19.5 & 7.24 \\
\hline Stipa capensis Thumb. & 32.1 & 28.90 & 78.30 & 12.40 & 44.88 & 16.68 \\
\hline
\end{tabular}




\subsection{Ecological characteristics of Perennial plants}

The results obtained from using the quadrat $4 \mathrm{~m}^{2}$ for perennial plants to study ecological characteristics, it showed that Plantago albicans has the highest density and frequency (14.7 plants $/ \mathrm{m}^{2}$ ) and $(97.8 \%)$ respectively, followed by Helianthemum lippii density with (3.26 plants $/ \mathrm{m}^{2}$ ) and frequency was (70.6\%). It's clear from the results that the highest value of abundance was 60.1 plant / quadrat for Plantago albicans followed by Asphodellus fisulosus with 20.6 plant / quadrat (Table 2).

Table 2. Showsthe Ecological characteristics of Perennial plants

\begin{tabular}{|c|c|c|c|c|c|c|}
\hline Species & $\begin{array}{c}\text { Density } \\
\left(\text { Plant } / \mathrm{m}^{2}\right)\end{array}$ & $\begin{array}{c}\text { Relative } \\
\text { density } \\
(\%)\end{array}$ & $\begin{array}{l}\text { Frequency } \\
\quad(\%)\end{array}$ & $\begin{array}{c}\text { Relative } \\
\text { frequency } \\
\%\end{array}$ & $\begin{array}{l}\text { Abundance } \\
\text { (Plant/ } \\
\text { quadrat) }\end{array}$ & $\begin{array}{c}\text { Relative } \\
\text { Abundance } \\
\%\end{array}$ \\
\hline Allium sativum (L.) & 0.01 & 0.04 & 1 & 0.23 & 4 & 1.34 \\
\hline $\begin{array}{l}\text { Argyrolobium } \\
\text { uniflorum (Decne.) } \\
\text { Jaub\&spal }\end{array}$ & 0.02 & 0.09 & 4.3 & 1.02 & 2 & 0.67 \\
\hline $\begin{array}{l}\text { Artemisia campetris } \\
\text { (L). }\end{array}$ & 0.01 & 0.04 & 3.2 & 0.76 & 2.3 & 0.77 \\
\hline $\begin{array}{l}\text { Asphodellus fisulosus } \\
\text { (L). }\end{array}$ & 0.73 & 3.34 & 14.1 & 3.36 & 20.6 & 6.91 \\
\hline $\begin{array}{l}\text { Calicotom villas } \\
\text { (poir.) link }\end{array}$ & 0.15 & 0.68 & 17.3 & 4.13 & 3.5 & 1.17 \\
\hline $\begin{array}{l}\text { Centauria dimorpha } \\
\text { Viv. }\end{array}$ & 0.08 & 0.36 & 7.6 & 1.81 & 0.4 & 0.13 \\
\hline $\begin{array}{l}\text { Cynodon dactylon } \\
\text { (L.)pers. }\end{array}$ & 0.76 & 3.48 & 1 & 0.23 & 140 & 46.9 \\
\hline $\begin{array}{l}\text { Echiochilon } \\
\text { fruticosum (Desf) }\end{array}$ & 0.4 & 1.83 & 46.7 & 11.16 & 3.4 & 1.14 \\
\hline $\begin{array}{l}\text { Erodium arborescens } \\
\text { (Dest.) Willd. }\end{array}$ & 0.02 & 0.09 & 3.2 & 0.76 & 3 & 1.00 \\
\hline $\begin{array}{l}\text { Euphorbia terracina } \\
\mathrm{L}\end{array}$ & 0.58 & 2.65 & 34.7 & 8.29 & 6.6 & 2.21 \\
\hline $\begin{array}{l}\text { Helianthemum lippii } \\
\text { (L.) Dum.Cours. }\end{array}$ & 3.26 & 14.9 & 70.6 & 16.8 & 18.5 & 6.20 \\
\hline $\begin{array}{l}\text { Kickxia aegyptiaca } \\
\text { (L.) Nabelek }\end{array}$ & 0.01 & 0.04 & 2.1 & 0.50 & 2.5 & 0.83 \\
\hline $\begin{array}{l}\text { Launaea reedifolia } \\
\text { (L.) O. kuntze }\end{array}$ & 0.47 & 2.15 & 28.2 & 6.73 & 7.5 & 2.51 \\
\hline Ononis natrix ( L). & 0.005 & 0.02 & 1 & 0.23 & 2 & 0.67 \\
\hline $\begin{array}{l}\text { Phagnalon rupestre } \\
\text { (L.) DC }\end{array}$ & 0.14 & 0.64 & 16.3 & 3.89 & 10.6 & 3.55 \\
\hline Plantago albicans L. & 14.7 & 67.3 & 97.8 & 23.3 & 60.1 & 20.1 \\
\hline $\begin{array}{l}\text { Retama raetam } \\
\text { (Forsk) we }\end{array}$ & 0.02 & 0.09 & 5.4 & 1.29 & 1.6 & 0.53 \\
\hline $\begin{array}{l}\text { Salvia lanigera } \\
\text { (Poir). }\end{array}$ & 0.002 & 0.009 & 1 & 0.23 & 1 & 0.33 \\
\hline $\begin{array}{l}\text { Stipa barbata } \\
\text { (Desf). }\end{array}$ & 0.3 & 1.37 & 30.4 & 7.26 & 4 & 1.34 \\
\hline $\begin{array}{l}\text { Thymelaea } \\
\text { microphylla (et Dur). }\end{array}$ & 0.06 & 0.27 & 9.7 & 2.31 & 2.5 & 0.83 \\
\hline
\end{tabular}


Budapest International Research in Exact Sciences (BirEx) Journal

Volume 1, No 4, October 2019, Page: 62-69

e-ISSN: 2655-7827 (Online), p-ISSN: 2655-7835 (Print)

www.bircu-journal.com/index.php/birex

emails: birex.journal@gmail.com

birex.journal.qa@gmail.com

\subsection{The plant cover}

Depending on the results obtained from using the line transect method to estimate the cover for each species and the total cover, it was found that the total cover $77.2 \%$, and the largest value of cover was $15.8 \%$ for Stipacapensis with a relative cover of $20.5 \%$, followed by Scabiosaarenaria with $11.7 \%$ (table 3).

Table 3. Shows the Cover and Relative Cover Each Species from the Line-Transect Method

\begin{tabular}{|c|c|c|}
\hline Plant species & Cover $(\%)$ & Relative Cover $(\%)$ \\
\hline Artemisia campestris L. & 0.19 & 0.15 \\
\hline Centauriadimorpha Viv. & 0.03 & 0.21 \\
\hline Chrysanthemum coronarium L. & 0.22 & 0.17 \\
\hline Launaea resedifolia (L.) O. Kuntze & 2.29 & 1.77 \\
\hline Phagnalon rupestre (L.) DC. & 0.61 & 0.46 \\
\hline Reichardia tingitana (L.) Roth & 1.70 & 1.31 \\
\hline Rhantherium suareolens Desf. & 0.10 & 0.078 \\
\hline Senecio gallicus Chiax & 0.78 & 0.6 \\
\hline Sonchus oleraceus L. & 0.36 & 0.28 \\
\hline Echiochilon fruticosum Desf. & 3.6 & 2.8 \\
\hline Brassica tournefortii Gouan & 1.54 & 1.19 \\
\hline Hussonia pinnata (Viv.) Jafri & 0.34 & 0.26 \\
\hline Chenopodium murale L. & 0.02 & 0.014 \\
\hline Helianthemum lippii (L.) Dum.Cours. & 6.7 & 5.2 \\
\hline Cuscuta sp. & 0.14 & 0.11 \\
\hline Scabiosa arenaria Forssk. & 15.2 & 11.7 \\
\hline Euphorbia terracina L. & 1.8 & 1.39 \\
\hline Astraguls serrtuloides L. & 0.2 & 0.23 \\
\hline Calicotom villosa (Poir.) Link & 5.05 & 3.9 \\
\hline Lotus halophilus Boiss.et Spruner & 1.8 & 1.43 \\
\hline Astraguls serrtuloides L. & 0.2 & 0.23 \\
\hline Ononis natrix L. & 0.06 & 0.052 \\
\hline Hippocrepis bicontorta Lois & 0.4 & 0.31 \\
\hline Retama raetam (forsk)We. & 4.36 & 3.3 \\
\hline $\begin{array}{l}\text { Argyrolobium } \\
\text { uniflorum(Decne.)Jaub\&spal }\end{array}$ & 0.11 & 0.082 \\
\hline Centaurium pulchellum (Swartz) Druce & 0.01 & 0.010 \\
\hline Erodium arborescens (Desf.) Willd. & 0.04 & 0.036 \\
\hline Salvialanigera Poir. & 0.03 & 0.026 \\
\hline Linumstrictum L. & 0.13 & 0.22 \\
\hline Asphodellus fistulosrs L. & 0.99 & 0.769 \\
\hline Eucalyptuscamaldulensis Dehnh. & 0.19 & 0.147 \\
\hline Plantago albicans L. & 16.17 & 12.4 \\
\hline Aegilopus kotschyi Boiss. & 1.34 & 1.03 \\
\hline Avenabarbata Pott ex Link & 1.18 & 0.91 \\
\hline BromusdiandrusRoth. & 0.97 & 0.75 \\
\hline Cenchrusciliaris(L.) Link & 0.25 & 0.2 \\
\hline Catapodiummarinum (L.) C.E.Hubb. & 0.16 & 0.13 \\
\hline Avelliniamichelii (Savi) Parl. & 0.06 & 0.052 \\
\hline Eragrostiscilianensis & 2.3 & 1.78 \\
\hline Stipabarbata Desf. & 5.8 & 4.5 \\
\hline Stipacapensis Thumb. & 20.5 & 15.8 \\
\hline Polygonumequisetiforme Sm. & 0.06 & 0.05 \\
\hline
\end{tabular}


Budapest International Research in Exact Sciences (BirEx) Journal

Volume 1, No 4, October 2019, Page: 62-69

e-ISSN: 2655-7827 (Online), p-ISSN: 2655-7835 (Print)

www.bircu-journal.com/index.php/birex

emails: birex.journal@gmail.com birex.journal.qa@gmail.com

\begin{tabular}{|l|l|l|}
\hline Anagallis arvensis L. & 1.45 & 1.12 \\
\hline Kickxiaaegyptiaca (L.) Nabelek & 0.16 & 0.12 \\
\hline Thymelaeamicrophylla Coss. et Dur. & 0.24 & 0.18 \\
\hline
\end{tabular}

\subsection{Importance Value (IV)}

The Importance Value (IV) for each species is resulting from the combined contribution of the relative cover, relative density and relative frequency of each species in the community. An importance valuesrange from 0 to 300, because it combines relative cover, density and frequency. According to the data obtained from this study, the importance values of species were recorded to be highest in Stipa capensis (187.92), following by Scabiosa arenaria (148.8) (Table 4).

Table 4. Shows the Importance Value from the Summation of the Relative Cover, Relative Density and Relative Frequency of each Plant Species

\begin{tabular}{|l|c|c|}
\hline \multicolumn{1}{|c|}{ Plantspecies } & $\begin{array}{c}\text { Importance } \\
\text { value }(300)\end{array}$ & $\begin{array}{c}\text { Importance } \\
\text { ratio(\%100) }\end{array}$ \\
\hline AegilopuskotschyiBoiss. & 22.38 & 7.46 \\
\hline Anagallisarvensis L. & 39.08 & 13.02 \\
\hline Argyrolobiumuniflorum (Decne.) Jaub\& spal & 5.47 & 1.82 \\
\hline Artemisia campetris L. & 0.99 & 0.33 \\
\hline Asphodellusfisulosus L. & 7.69 & 2.56 \\
\hline Avenabarbata Pott ex Link & 8.54 & 2.84 \\
\hline Calicotomvillas (poir.) link & 9.86 & 3.28 \\
\hline Centauria dimorpha Viv & 2.2 & 0.7 \\
\hline Centauriumpulchellum (Swartz) Druce & 8.41 & 2.80 \\
\hline Echiochilonfruticosum ( Desf) & 16.59 & 5.53 \\
\hline Eragrostiscilianensis & 51.9 & 17.3 \\
\hline Erodiumarborescens (Dest.) Willd. & 0.89 & 0.29 \\
\hline EuphorbiaterracinaL. & 12.74 & 4.24 \\
\hline Helianthemumlippii (L.) Dum.Cours. & 38.4 & 12.8 \\
\hline Hippocrepisbicontorta Loisel. & 29.79 & 9.93 \\
\hline Hussoniapinnata (Viv.) Jafri & 8.6 & 2.86 \\
\hline Kickxia aegyptiaca (L.) Nabelek & 0.7 & 0.23 \\
\hline Launaeareedifolia (L.) O. kuntze & 11.17 & 3.72 \\
\hline Linumstrictum L. & 5.27 & 1.75 \\
\hline Lotus halophilus Boiss.et Spruner & 92.71 & 30.90 \\
\hline Ononisnatrix L. & 0.31 & 0.10 \\
\hline Phagnalonrupestre (L.) DC & 5.14 & 1.71 \\
\hline Plantagoalbicans L. & 106.77 & 35.3 \\
\hline Reichardiatingitana (L.)Roth. & 7.64 & 2.54 \\
\hline Reichardia tingitana (L.) Roth & 10.94 & 3.64 \\
\hline Retamaraetam (forsk) we & 5.74 & 1.91 \\
\hline Salvialanigera Poir. & 0.26 & 0.08 \\
\hline Scabiosa arenaria Forssk. & 148.8 & 49.6 \\
\hline Stipa barbata Desf. & 14.43 & 4.81 \\
\hline Stipa capensis Thumb. & 187.92 & 62.64 \\
\hline Thymelaea microphylla et Dur & 2.82 & 0.94 \\
\hline
\end{tabular}




\section{Discussion}

The results of this field study showed that the annual plants have the highest density (32.1 plant $/ \mathrm{m}^{2}$ ) for Stipacapensis, followed by Scabiosaarenaria (value $15.6 \mathrm{plant} / \mathrm{m}^{2}$ ), while the highest frequency (80\%) for Scabiosaarenaria, then Stipacapensis by (78.8\%); Whereas, in perennial plants, the results showed that the species Plantagoalbicans has the highest density andfrequency were (14.7 plant $/ \mathrm{m}^{2}$ ) and $(97.8 \%)$ respectively, followed by Helianthemumlippii with a density (3.26 plant $/ \mathrm{m}^{2}$ ) and frequency ratio $(70.6 \%)$. In the annual plant, results showed that the largest cover was recorded for Stipacapensis (15.8\%), followed by Scabiosaarenaria (11.7\%), while in the perennial plants $P$. albicans recorded the highest cover $(12.4 \%)$, followed by the plant species $H$. lippii (5.2\%). The results showed that the highest importance value of the plant species was (187.92) for S.capensis followed by S. arenaria (148.8).These results are expected because the study area was exposed to a widespread fire and its effects are obvious on the remnants of the burning bushes and perennial plants. This made the vegetation in the study area, enter into a process of secondary environmental succession; due to this, it was found that the annual plants are dominant cover in the study area by (Stipa capensis Scabiosa arenaria- community).

\section{Conclusion}

The present study is the first research to investigate the vegetation characteristics of the protected area, which is located within the campus of the University of Tripoli, to know the dominant species because it never has been ecologically studied before. Therefore,two methods were used Quadrat Method and Lines-transect Method. 19 lines-transect were randomly distributed with a length of 50 meters in the study area. A total of 92 quadrats $4 \mathrm{~m} 2$ selected for perennial plants and 60 quadrats $1 \mathrm{~m} 2$ for annual plants (grasses) were distributed to the Line-transect; all plant species and their numbers that appeared in the quadrat were recorded. The results showed that the highest density in annual plants was 32.1 plant / $\mathrm{m} 2$ for Stipacapensis followed by Scabiosa arenaria with 15.6 plant / $\mathrm{m} 2$, and the highest importance value of the plant species was (187.92) for S.capensis followed by S. arenaria (148.8). Consequently, from the results obtained, the plant's community of the study area is Stipacapensis - Scabiosaarenaria Community.

\section{References}

Ali, S. I., Jafri, S. M. H. \& El-Gadi, A. (Eds), 1977-1989: Flora of Libya, 1-147. - Tripoli.

Askari, Y., Kafash,E. S., \&Rezaei,D. (2013). Evaluation of different sampling methods to study of shrub density in Zagros forest.European Journal of Experimental Biology, 3, 121-128.

Balouchi, F., Ebrahimi, M., \&Taheri, M. (2017). Efficiencies of Two Distance Methods in Estimating Plant Density in Shrublands (Case Study: Tange-Sarheh, Nikshahr). InternationalJournal of Agriculture Innovations and Research,6(2):2319-1473.

Betelmal, A.G. (2010).Classification of the Vegetation cover in the Pasture of Faculty of Agriculture Al Fateh University, Libya. Ass. Univ. Bull. Environ. Res. 13:2.

Buckland, S.T., Borchers, D.L., Johnston, A., Henrys, P.A. \& Marques, T.A. 2007.Line transect methods for plant surveys. Biometrics63, 989-998. 
Cain, S. A., \& Castro, G. M. (1959).Manual of vegetation analysis. Harper, New York. 325p. Clarendon Press, Oxford.

Cardinale, B. J., Duffy, J. E., Gonzalez, A., Hooper, D. U., Perrings, C., Venail, P., Narwani, A., Mace, G. M., Tilman, D., Wardle, D. A., Kinzig, A. P., Daily, G. C., Loreau, M., Grace, J. B., Larigauderie, A., Srivastava, D. S. and Naeem, S. (2012). 'Biodiversity loss and its impact on humanity', Nature 486:59-67.

CBD Secretariat. (2010).The Strategic Plan for Biodiversity 2011-2020 and the Aichi Biodiversity Targets. Document UNEP/CBD/COP/DEC/X/2.Secretariat of the Convention on Biological Diversity, Nagoya, Japan.

DeFries, R., Hansen, A., Turner, BL., Reid, F.,\& Liu J. (2007). Land use change around protected areas: management to balance human needs and ecological function. Ecological Applications, 17(4),1031-1038.

Gayton, D. ( 2013). Grassland and forest understorey vegetation monitoring: An introduction to field methods. Journal of Ecosystems and Management, 14(3):1-9.

IUCN. (1994). Guidelines for Protected Area Management Categories. IUCN, Gland,

Krebs C.J.(1999). Ecological Methodology. AddisonWesley Longman, New York, NY, USA, 2nd edition.

Liu,S., Baret,F., Allard,D., Jin,X., Andrieu, B., Burger,P.,Hemmerlé, M., \&Comar, A.(2017). A method to estimate plant density and plant spacing heterogeneity: application to wheat crops. Plant Methods,13:38. http://dx.doi.org/10.1186/s13007-017-0187-1

Mahajan, M. \& Fatima, S. (2017).Frequency, Abundance and Density of plant species by listcount Quadrat Method.International Journal of Multidisciplinary Research,III(VII): 21-28.

Sorrells, L. \& Glenn, S. (1991). Review of Sampling Techniques used in Studies of Grassland Plant Communities. Proc. Okla. Acad. Sci.71:43-45.Switzerland and Cambridge, UK. 